\title{
Phosphorus depletion in sheep and the ratio of calcium to phosphorus in the diet with reference to calcium and phosphorus absorption
}

\author{
By V. R. YOUNG,* W. P. C. RICHARDS, G. P. LOFGREEN \\ AND J. R. LUICK \\ Departments of Animal Husbandry and Veterinary Pathology, \\ University of California, Davis, California, USA
}

(Received I 4 February 1966-Accepted 27 Fune 1966)

\begin{abstract}
I. A total of sixty-three wether lambs, 4-6 months old, were fed on diets low in phosphorus and adequate in calcium $(0.072-0.073 \% \mathrm{P}, 0.38-0.40 \% \mathrm{Ca})$ or adequate in both $(0.38-0.40 \%$ $\mathrm{P}, 0.40 \% \mathrm{Ca}$ ) for $\mathrm{I} 34$ or 142 days. 2. Concentrations of serum inorganic $\mathrm{P}$ and $\mathrm{Ca}$ and alkaline phosphatase activity were studied during the depletion period. Bones were taken for histological analysis at the end of the $\mathrm{I}_{42}$ days. 3. After the preliminary depletion period, a metabolism study was conducted in which the effects of previous $P$ depletion and dietary $\mathrm{Ca}: \mathrm{P}$ ratio upon $\mathrm{Ca}$ and $\mathrm{P}$ absorption, as measured by isotope techniques, were studied. 4. Histological analysis of bones showed the presence of lesions characteristic of late rickets in some sheep and of severe osteoporosis in others. 5. A wide dietary Ca: $\mathrm{P}$ ratio had no apparent effect on $P$ absorption when $P$ intake was adequate. The availability of $P$ was lowered by a diet deficient in $P$ with a wide Ca: $P$ ratio. 6 . Previous $P$ depletion resulted in enhanced $P$ absorption during the first $1 \times \cdot 5$ days after an increased intake of $P$, but this effect was not shown during days $\mathrm{I4}^{-2} \mathrm{I}$ after the increase. 7. Ca absorption was reduced by giving a diet low in $\mathrm{P}$ and was increased when the intake of $\mathrm{P}$ was raised. 8. The response to wide dietary $C a: P$ ratios by ruminants and non-ruminants is reviewed, and a hypothesis, based upon a knowledge of the intestinal reaction of these species, is offered for the finding that ruminants tolerate wider dietary $\mathrm{Ca}: \mathrm{P}$ ratios than non-ruminant species.
\end{abstract}

Since the first detailed report on the dietary influence of the calcium to phosphorus ratio by McCollum, Simmonds, Shipley \& Park (I92I), the interaction between Ca and $P$ in nutrition has been the subject of many investigations. Results with the rat, pig, fox, and chick (Bethke, Steenbock \& Nelson, 1923-4; Lloyd, Crampton \& Mowat, I96I; Harris, Bassett \& Wilke, I95 ; Mraz, I96r) suggest that the ratio of dietary $\mathrm{Ca}$ to $\mathrm{P}$ should be maintained within relatively narrow limits in order to secure maximum growth rates. In contrast, ruminant animals appear to be less sensitive to the ratio of dietary $\mathrm{Ca}$ to $\mathrm{P}$ (Theiler, du'Toit \& Malan, 1937; Huffman, Robinson \& Winter, 1930). However, recently Wise, Ordoveza \& Barrick (1963) and Dowe, Matsushima \& Arthaud (1957), working with ruminants, have shown that above a ratio of $8:$ I performance and nutrient conversion are reduced.

In much of this work mineral balance, plasma levels of these elements, bone ash and body-weight gain, were used as measures of response. Few studies have been concerned with the influence of the dietary $\mathrm{Ca}: \mathrm{P}$ ratio on the absorption of these elements. Lueker \& Lofgreen (I96I), using an isotope dilution technique, did not find any influence of ratios between $0 \cdot 8: 1$ and $6: I$ on the absorption of $P$ when this

* Present address: Department of Nutrition and Food Science, Massachusetts Institute of Technology, Cambridge, Massachusetts, USA. 
element was given to sheep at a level sufficient to promote adequate growth. Since a $C a: P$ ratio of $6: I$ allowed for adequate growth in ruminants when the $P$ intake was adequate, it may be that a higher ratio in conjunction with a deficiency of $\mathrm{P}$ would have resulted in a depressed availability of the dietary $P$.

In relation to gastro-intestinal absorption, the influence of previous $\mathrm{Ca}$ nutrition on the absorption of $\mathrm{Ca}$ has been studied extensively. It is well established that rats adapt to a low $\mathrm{Ca}$ intake by increasing the rate at which they absorb this element when subsequently given an adequate amount of Ca (Rottensten, I938; Henry \& Kon, r953). This has also been shown in the ruminant animal (Luick, Boda \& Kleiber, I957). The question of whether animals are able to adapt in a similar manner to a reduced $P$ intake has received little attention. Hansard \& Plumlee (I954) suggest that a greater influence is exerted upon retention than upon the absorption of $P$ in the rat. Furthermore, Rasmussen \& DeLuca (1963) state that: 'There is no good evidence that an active process of gastro-intestinal $\mathrm{P}$ absorption has been developed to conserve the $\mathbf{P}$ of the diet.'

Since ruminant diets generally contain a high proportion of roughage, the supply of dietary $\mathrm{Ca}$ usually is adequate; but dietary $\mathrm{P}$ is often limiting (Hill, r963). From this standpoint, it appeared worth while to study the effects of $\mathbf{P}$ deficiency and the dietary $\mathrm{Ca}: \mathrm{P}$ ratio, with both adequate and deficient intakes of $\mathrm{P}$ upon the absorption of these elements in the ruminant.

Wether sheep were depleted of their body P on a diet low in P for I 34 or 142 days. Histological analysis of bones at the end of this period indicated the presence of late rickets in some sheep and severe osteoporosis in others. A wide dietary $\mathrm{Ca}: \mathrm{P}$ ratio did not depress the absorption of $\mathrm{P}$ when intake of the element was adequate. $P$ depletion resulted in enhanced $\mathbf{P}$ absorption during a short period following an increase in the intake of $P$.

\section{EXPERIMENTAL}

\section{Diets and general technique}

Sixty-three wether lambs, 4-6 months of age, were fed, ad lib., on a diet low in $\mathrm{P}$ and adequate in $\mathrm{Ca}(0.072-0.073 \% \mathrm{P}, 0.38-0.40 \% \mathrm{Ca})$ or adequate in both $(0.38-$ $0.40 \% \mathrm{P}, 0.40 \% \mathrm{Ca}$ ). The composition of these diets has been reported by Young, Luick \& Lofgreen (r966). The experiment was divided into two trials; thirty-two lambs were used in trial I lasting I 34 days and thirty-one in trial 2 lasting 142 days. During the depletion period blood samples were taken by jugular puncture at $06 \cdot 00 \mathrm{~h}$ every $3^{\text {rd }}$ week. Bones were taken from some sheep at the end of the period for histological examination.

Following this period nine $\mathrm{P}$-depleted and nine control sheep, randomly chosen from each of the depleted and control groups in each trial, were studied in two $2 \mathrm{I}$-day metabolism trials. Three test diets were given, their constituents and chemical composition, determined by methods suggested by the Association of Official Agricultural Chemists (1960), are given in Tables I and 2 , respectively. The sheep were fed at $75 \%$ of their previous ad lib. intake, except for controls receiving diet $\mathrm{I}$. The 
controls received $66 \%$ of their ad lib. intake, in anticipation of a decline in intake during the metabolism trial because of the low $P$ content of the diet.

Animals were accustomed to the metabolism stalls and test diets during a 4-day preliminary period and were then injected subcutaneously with ${ }^{32} \mathrm{P}$ (4.5 $\mathrm{mc}$ and $4.9 \mathrm{mc} / \mathrm{lamb}$ in the first and second trials, respectively) and ${ }^{45} \mathrm{Ca}(2.5 \mathrm{mc}$ and $2.8 \mathrm{mc} /$ lamb in the first and second trials, respectively). Isotopes were prepared separately for injection by dilution in physiological saline and adjusted to near neutrality with weak $\mathrm{NaOH}$. One isotope was given on each side of the vertebral column in the area of the tail-head. The metabolism study was divided into two collection periods, period I covering days 4-IO.5 (trial I) and days 4-II.5 (trial 2) after feeding with

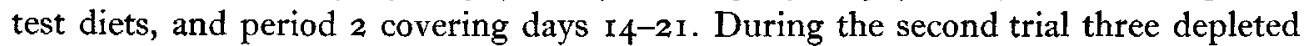
sheep, one receiving each test diet, failed to eat their allowance and hence results for these sheep are not reported. Collections of excreta were made at $06.00 \mathrm{~h}$ and blood samples were taken by jugular puncture at intervals after isotope injection.

Table I. Composition (\%) of the diets given to phosphorus-depleted and control sheep during the metabolism trials

\begin{tabular}{|c|c|c|c|}
\hline \multirow[b]{2}{*}{ Constituent } & \multicolumn{3}{|c|}{ Diet no. } \\
\hline & I & 2 & 3 \\
\hline Beet pulp, dried & $61 \cdot 0$ & $6 r \cdot 0$ & $56 \cdot 3$ \\
\hline Molasses & $10 \cdot 0$ & 10.0 & $10 \cdot 0$ \\
\hline Barley straw & $10 \cdot 0$ & $10 \cdot 0$ & $10 \cdot 0$ \\
\hline Pearl starch & 16.0 & 16.0 & $16 \cdot 0$ \\
\hline Urea & I'5 & I'5 & $1 \cdot 5$ \\
\hline Trace-mineralized salt* & 0.5 & 0.5 & 0.5 \\
\hline Vitamins $A$ and $D$ concentrate $\nmid$ & + & + & + \\
\hline $\mathrm{CaCO}_{3}$ & $1 \cdot 0$ & 0.24 & $5 \cdot 0$ \\
\hline $\mathrm{NaH}_{2} \mathrm{PO}_{4}$ & - & 0.66 & 0.70 \\
\hline
\end{tabular}

* Supplied not less than: $96.5 \% \mathrm{NaCl}, 0.2 \% \mathrm{Mn}, 0.16 \% \mathrm{Fe}, 0.033 \% \mathrm{Cu}, 0.01 \% \mathrm{Co}, 0.007 \% \mathrm{I}$, $0.005 \%$ Zn (Morton Salt Co., Chicago, Illinois, USA).

$\dagger 2640$ i.u. vitamin $A$ and 330 i.u. vitamin $D_{2}$ per $k g$ diet.

Table 2. Chemical composition (\% of dry matter) of the diets given to phosphorus-depleted and control sheep during the metabolism trials

\begin{tabular}{|c|c|c|c|}
\hline \multirow[b]{2}{*}{ Constituent } & \multicolumn{3}{|c|}{ Diet no. } \\
\hline & I & 2 & 3 \\
\hline Nitrogen & $I \cdot 60$ & $I \cdot 53$ & $I \cdot 49$ \\
\hline Crude fibre & $15 \cdot 17$ & 15.67 & $14 \cdot 52$ \\
\hline Ether extract & $0 \cdot 33$ & 0.30 & 0.30 \\
\hline Ash & $7 \cdot 68$ & $7 \cdot 20$ & $12 \cdot 33$ \\
\hline Calcium & 0.789 & 0.480 & 2.610 \\
\hline Total P & 0.076 & 0.248 & 0.264 \\
\hline Ca:P ratio & $10.4: 1$ & $I \cdot 9: I$ & $9 \cdot 9: 1$ \\
\hline
\end{tabular}

No phytate $P$ was detected in any of the diets.

\section{Analytical methods}

The methods used for the determination of $\mathrm{Ca}$ and $\mathrm{P}$ in urine, faeces and serum and for the radioactivity measurements have been described by Young et al. (rg66). 
Alkaline phosphatase was assayed by the method of Lowry (I957) using disodium para-nitrophenol phosphate as the substrate. The $\mathrm{pH}$ optimum under the conditions of our assay was found to be $10 \cdot 2-10 \cdot 3$.

To estimate the quantity of dietary element absorbed, a determination of the metabolic faecal $\mathrm{Ca}$ and $\mathrm{P}$ excretion was made. For period I the determination was based upon the model described by Aubert, Bronner \& Richelle (1963), details of which have been given by Young et al. (1966). Since the urinary activities of $\mathrm{Ca}$ and $\mathrm{P}$ were low during period 2, the method of calculation for this period was based upon the isotope dilution principle described by Kleiber, Smith, Ralston \& Black (195I) and reviewed by Thompson (1965).

Statistical evaluation of the results was performed according to conventional procedures. Analysis of variance involved the use of a harmonic mean because of the resultant unequal subclass numbers in the experimental design. Results from both metabolism trials were similar, and the values have been combined.

\section{RESULTS}

\section{Depletion period}

The mean initial and final serum $\mathrm{P}$ and $\mathrm{Ca}$ contents and serum alkaline phosphatase activity for the various groups of sheep are given in Table 3 . In both control groups serum $P$ concentration increased during the period of experimental study, a finding which also applies to serum alkaline phosphatase activity. In the depleted groups the serum alkaline phosphatase activity was no higher than in the control groups, after $\mathrm{I} 34^{-} \mathrm{I} 42$ days of $\mathrm{P}$ depletion.

Table 3. Mean initial and final values with their standard errors for serum constituents in sheep fed on low-phosphorus and control-P diets for 134 (trial I) and 142 (trial 2) days

\begin{tabular}{|c|c|c|c|c|c|c|c|c|}
\hline \multirow[b]{2}{*}{ Diet } & \multirow{2}{*}{$\begin{array}{c}\text { Trial } \\
\text { no. }\end{array}$} & \multirow{2}{*}{$\begin{array}{c}\text { No. } \\
\text { of } \\
\text { sheep }\end{array}$} & \multicolumn{2}{|c|}{$\begin{array}{l}\text { Inorganic P } \\
(\mathrm{mg} / \mathrm{r} 00 \mathrm{ml})\end{array}$} & \multicolumn{2}{|c|}{ Calcium $(\mathrm{mg} / 100 \mathrm{ml})$} & \multicolumn{2}{|c|}{$\begin{array}{l}\text { Alkaline phosphatase } \\
\text { (m-moles substrate } \\
\text { converted/h per } 1 \text { ) }\end{array}$} \\
\hline & & & Initial & Final & Initial & Final & Initial & Final \\
\hline Low-P & $\begin{array}{l}\text { I } \\
2\end{array}$ & $\begin{array}{l}14 \\
14\end{array}$ & $\begin{array}{l}6 \cdot x \pm 0.56 \\
7 \cdot 6 \pm 0.20\end{array}$ & $\begin{array}{l}3 \cdot 6 \pm 0.39 \\
4 \cdot 5 \pm 0.31\end{array}$ & $\begin{array}{l}10.8 \pm 0.25 \\
10.8 \pm 0.13\end{array}$ & $\begin{array}{l}11.5 \pm 0.22 \\
10.8 \pm 0.35\end{array}$ & $\begin{array}{l}4.3 \pm 0.37 \\
7.7 \pm 0.65\end{array}$ & $\begin{array}{l}16 \cdot 6 \pm 1 \cdot 79 \\
14.9 \pm 2 \cdot 44\end{array}$ \\
\hline Control-P & $\begin{array}{l}1 \\
2\end{array}$ & $\begin{array}{l}14 \\
14\end{array}$ & $\begin{array}{l}8.8 \pm 0.47 \\
7.3 \pm 0.38\end{array}$ & $\begin{array}{l}9.7 \pm 0.50 \\
9.8 \pm 0.42\end{array}$ & $\begin{array}{l}10.3 \pm 0.21 \\
10.5 \pm 0.11\end{array}$ & $\begin{array}{r}9.12 \pm 0.27 \\
9.3 \pm 0.17\end{array}$ & $\begin{array}{l}4.3 \pm 0.48 \\
7.7 \pm 0.82\end{array}$ & $\begin{array}{l}13.9 \pm 1.66 \\
16.5 \pm x \cdot 63\end{array}$ \\
\hline
\end{tabular}

Gross examination of the bones showed that those from depleted sheep had a much thinner cortex, were softer to cut and had less well developed trabeculae in the metaphysis and epiphysis. Histological sections of selected bones are illustrated in Pl. I $a$ for a depleted sheep and may be compared with those from a control sheep (Pl. I b). Examination of the long bones and ribs revealed that the main lesion in the diaphysis was a decrease in the thickness of the cortex with slight widening of the Haversian canals. The lesions in the metaphysis were severe: a reduction in the amount of trabecular bone resulting from a decrease in both size and number of trabeculae. Around trabeculae in the bones of some sheep excessive osteoid was seen 
in the form of narrow borders, but osteoblastic and osteoclastic activity was only slightly increased over that of normal bones. The articular cartilage was normal and covered an epiphysis that had narrow trabeculae and wide intertrabecular spaces occupied by fat; some trabeculae were coated, in part, by narrow osteoid borders. In the mandible the changes were essentially similar to those in the long bones. A decrease in the thickness of the cortex was noted, and increased osteoblastic activity was seen best in the tissue about the alveolae.

The classification of these bone lesions presented some difficulty. It was found that a considerable reduction of mineralized tissue had occurred in all sheep examined on the P-deficient diet; but, while some sheep had lesions typical of osteoporosis without excessive osteoid, others had lesions of late rickets and displayed narrow osteoid borders surrounding the trabeculae.

Table 4. Mean values with their standard errors for phosphorus intake and absorption of five $P$-depleted and six control sheep fed on diets varying in Ca:P ratio and in $P$ content

\begin{tabular}{|c|c|c|c|c|c|}
\hline $\begin{array}{l}\text { Diet } \\
\text { no. }\end{array}$ & $\begin{array}{l}\mathrm{Ca}: \mathrm{P} \\
\text { ratio }\end{array}$ & P status & Intake ( $\mathrm{g} /$ week) & $\begin{array}{l}\text { Absorbed } \\
\text { (g/week) }\end{array}$ & $\begin{array}{l}\% \text { intake } \\
\text { absorbed }\end{array}$ \\
\hline \multicolumn{6}{|c|}{ Period I } \\
\hline I & $10.4: 1$ & $\begin{array}{l}\text { Depleted } \\
\text { Control }\end{array}$ & $\begin{array}{l}3 \cdot 0 \pm 0 \cdot 38 \\
3 \cdot 6 \pm 0 \cdot 36\end{array}$ & $\begin{array}{l}1 \cdot 9 \pm 0.64 \\
2 \cdot 4 \pm 0.59\end{array}$ & $\begin{array}{l}64 \cdot 1 \pm 12 \cdot 2 \\
65 \cdot 8 \pm 9 \cdot 6\end{array}$ \\
\hline 2 & I'9:I & $\begin{array}{l}\text { Depleted } \\
\text { Control }\end{array}$ & $\begin{array}{r}9.5 \pm 0.63 \\
12.7 \pm 1.08\end{array}$ & $\begin{array}{l}8.3 \pm 0.27 \\
7.4 \pm 1.06\end{array}$ & $\begin{array}{l}86.8 \pm 5.2 \\
57.7 \pm 5.8\end{array}$ \\
\hline 3 & $9 \cdot 9: \mathrm{I}$ & $\begin{array}{l}\text { Depleted } \\
\text { Control }\end{array}$ & $\begin{array}{l}10.4 \pm 0.72 \\
14.8 \pm 1.01\end{array}$ & $\begin{array}{r}9.6 \pm 0.59 \\
10.7 \pm 1.16\end{array}$ & $\begin{array}{l}92 \cdot 4 \pm 1 \cdot 7 \\
72 \cdot 3 \pm 6 \cdot 7\end{array}$ \\
\hline \multicolumn{6}{|c|}{ Period 2} \\
\hline I & IO $4: 1$ & $\begin{array}{l}\text { Depleted } \\
\text { Control }\end{array}$ & $\begin{array}{l}3 \cdot 0 \pm 0 \cdot 37 \\
3 \cdot 6 \pm 0.36\end{array}$ & $\begin{array}{l}1 \cdot 6 \pm 0.27 \\
2 \cdot 4 \pm 0.59\end{array}$ & $\begin{array}{l}53.7 \pm 6 \cdot 5 \\
65.8 \pm 2 \cdot 5\end{array}$ \\
\hline 2 & $I \cdot 9: I$ & $\begin{array}{l}\text { Depleted } \\
\text { Control }\end{array}$ & $\begin{array}{r}9.5 \pm 0.63 \\
+3.2 \pm 0.82\end{array}$ & $\begin{array}{l}7.2 \pm 0.45 \\
9.5 \pm 0.58\end{array}$ & $\begin{array}{l}76 \cdot 1 \pm 3.8 \\
72 \cdot 3 \pm 3 \cdot 4\end{array}$ \\
\hline 3 & $9 \cdot 9: 1$ & $\begin{array}{l}\text { Depleted } \\
\text { Control }\end{array}$ & $\begin{array}{l}10.2 \pm 0.77 \\
14.8 \pm 1 \cdot 01\end{array}$ & $\begin{array}{r}8.1 \pm 0.50 \\
10.5 \pm 0.53\end{array}$ & $\begin{array}{l}80 \cdot 4 \pm 4 \cdot 6 \\
71 \cdot 8 \pm 3 \cdot 8\end{array}$ \\
\hline
\end{tabular}

\section{Metabolism study}

Table 4 summarizes the results obtained for $\mathbf{P}$ absorption. The amount of $\mathbf{P}$ absorbed was significantly correlated with $\mathrm{P}$ intake $(r=0.90, P<0.0 \mathrm{I}$ for period $\mathrm{I}$ and $r=0.96, P<0.01$ for period 2). The percentage of the $\mathrm{P}$ intake which was absorbed (availability) was lower on the diet with a $\mathrm{Ca}: \mathrm{P}$ ratio of $\mathrm{IO}: \mathrm{I}$ and deficient $\mathrm{P}$ (diet $\mathrm{I}$ ) than on the other diets, both adequate in P. Analysis of variance on $\mathrm{P}$ availability indicated a significant difference $(P<0.01)$ between diets during period 2 , but owing to greater variability during period $\mathrm{I}$ the difference was not statistically significant $(P>0 \cdot 1)$. However, during the first period the lowest mean availability of $P$ was again with the diet deficient in $P$. These results suggest that a wide ratio of $\mathrm{Ca}$ to $\mathrm{P}$ has little effect on $\mathrm{P}$ absorption when $\mathrm{P}$ intake is adequate, but the availability is depressed when a wide ratio of $\mathrm{Ca}$ to $\mathrm{P}$ is given in conjunction with a deficient $\mathrm{P}$ intake. The differences in the mean quantities of $P$ absorbed with diets $I$ and 2 remained statistically significant $(P<0.01)$ when covariance adjustment was made 
to equalize $\mathrm{P}$ intakes in the two diets but were not statistically different when both $\mathrm{P}$ and $\mathrm{Ca}$ intakes were equalized $(P>0.05)$. This statistical analysis suggests that the wide ratio of $\mathrm{Ca}$ to $\mathrm{P}$ resulted in a decreased availability of $\mathrm{P}$ in diet $\mathrm{I}$ but does not eliminate the possibility that the dietary concentration of $P$ is important in determining the extent to which dietary $\mathrm{P}$ is absorbed. It is conceivable that there is a threshold concentration of $\mathbf{P}$ in the intestine below which absorption can take place to only a small extent.

The influence of previous $\mathrm{P}$ depletion is also shown in Table 4. During period I the depleted lambs receiving diets 2 and 3 absorbed $P$ more efficiently than their controls $(P<0.0 \mathrm{I})$. This was not repeated during the second period and it appears that the influence of previous depletion upon $P$ absorption was of relatively short duration. The depleted sheep fed on diet I absorbed $\mathrm{P}$ less efficiently during the second period than the control sheep on this diet. The reason for this finding is not clear, but may be associated with a stress imposed by a 3 -week confinement in metabolism stalls. This is, however, only conjectural and the possibility needs to be experimentally examined.

Table 5. Mean values with their standard errors for calcium intake and absorption of five phosphorus-depleted and six control sheep fed on diets varying in Ca:P ratio and $P$ content

\begin{tabular}{|c|c|c|c|c|c|}
\hline $\begin{array}{l}\text { Diet } \\
\text { no. }\end{array}$ & $\begin{array}{l}\text { Ca: } P \\
\text { ratio }\end{array}$ & P status & $\begin{array}{l}\text { Intake* } \\
\text { (g/week) }\end{array}$ & $\begin{array}{l}\text { Absorbed } \\
\text { (g/week) }\end{array}$ & $\begin{array}{l}\% \text { intake } \\
\text { absorbed }\end{array}$ \\
\hline \multicolumn{6}{|c|}{ Period I } \\
\hline 1 & $10.4: 1$ & $\begin{array}{l}\text { Depleted } \\
\text { Control }\end{array}$ & $\begin{array}{l}31 \cdot x \pm 3 \cdot 41 \\
38 \cdot I \pm 2 \cdot 98\end{array}$ & $\begin{array}{l}7 \cdot 0 \pm 1 \cdot 02 \\
7 \cdot 8 \pm I \cdot 18\end{array}$ & $\begin{array}{l}22 \cdot 8 \pm 3 \cdot 0 \\
20 \cdot 6 \pm 3 \cdot 9\end{array}$ \\
\hline 2 & $I \cdot 9: I$ & $\begin{array}{l}\text { Depleted } \\
\text { Control }\end{array}$ & $\begin{array}{l}18.8 \pm 2.18 \\
23.5 \pm 2.07\end{array}$ & $\begin{array}{l}7 \cdot 0 \pm 1 \cdot 38 \\
6 \cdot 9 \pm 0.99\end{array}$ & $\begin{array}{l}37 \cdot 1 \pm 8 \cdot 7 \\
29 \cdot 2 \pm 2 \cdot 7\end{array}$ \\
\hline 3 & $9 \cdot 9: \mathrm{I}$ & $\begin{array}{l}\text { Depleted } \\
\text { Control }\end{array}$ & $\begin{array}{l}104.9 \pm 10.24 \\
142 \cdot 3 \pm 12 \cdot 13\end{array}$ & $\begin{array}{l}31.0 \pm 2.45 \\
20.4 \pm 2.14\end{array}$ & $\begin{array}{l}29 \cdot 5 \pm 2 \cdot 5 \\
\mathrm{I} 4 \cdot 3 \pm \mathrm{I} \cdot 8\end{array}$ \\
\hline \multicolumn{6}{|c|}{ Period 2} \\
\hline $\mathbf{I}$ & $10 \cdot 4: I$ & $\begin{array}{l}\text { Depleted } \\
\text { Control }\end{array}$ & $\begin{array}{l}30.8 \pm 3.50 \\
38.1 \pm 2.98\end{array}$ & $\begin{array}{l}5 \cdot 1 \pm x \cdot 21 \\
6 \cdot 5 \pm 0.71\end{array}$ & $\begin{array}{l}16 \cdot 5 \pm 2 \cdot 1 \\
16 \cdot 9 \pm 1 \cdot 3\end{array}$ \\
\hline 2 & $I \cdot 9: I$ & $\begin{array}{l}\text { Depleted } \\
\text { Control }\end{array}$ & $\begin{array}{l}18.8 \pm 2.18 \\
24.4 \pm 1.63\end{array}$ & $\begin{array}{l}7.7 \pm 0.77 \\
6.6 \pm \mathrm{r} \cdot 82\end{array}$ & $\begin{array}{l}4 I \cdot 8 \pm 4 \cdot I \\
26 \cdot 3 \pm 4 \cdot I\end{array}$ \\
\hline 3 & $9 \cdot 9: 1$ & Depleted & $105.3 \pm 10.20$ & $23.5 \pm 5.68$ & $22 \cdot 3 \pm 4 \cdot 7$ \\
\hline & & Control & $142 \cdot 3 \pm 12.13$ & $24 \cdot 4 \pm 3 \cdot 37$ & $17 \cdot 1 \pm 1 \cdot 5$ \\
\hline
\end{tabular}

* Intake of $\mathrm{Ca}$ in the drinking water has not been taken into account; analysis of the water revealed a concentration of $16 \mathrm{mg} \mathrm{Ca/1}$.

The results summarizing $\mathrm{Ca}$ absorption are given in Table 5 , and the relationship between intake and absorption in sheep fed on the three diets is illustrated in Fig. $\mathrm{I}$. This graph shows that although the $\mathrm{P}$-deficient diet (diet $\mathrm{r}$ ) supplied more $\mathrm{Ca}$ than diet 2 (Ca:P ratio $\mathrm{I} \cdot 9: \mathrm{I}$ ) the rate of $\mathrm{Ca}$ absorption was lower for the group receiving the deficient diet. When the amount absorbed was adjusted to equal rates of intake, the difference was statistically significant $(P<0.01)$ in both periods. This finding suggests that the rate of $\mathrm{Ca}$ absorption may be reduced when $\mathrm{P}$ intake is deficient.

The influence of previous $\mathbf{P}$ depletion on the rate of $\mathrm{Ca}$ absorption is shown in Table 5. The $\mathrm{P}$-depleted sheep fed on diets 2 and 3 absorbed $\mathrm{Ca}$ at a relatively higher 
rate than the control groups during period $\mathbf{I}$ although the difference was only significant for those fed on diet 3 . During the second period, the P-depleted sheep fed on diet $\mathbf{2}$ continued to absorb $\mathrm{Ca}$ at a higher rate than their controls, but the difference was not statistically significant $(P>0.05)$.

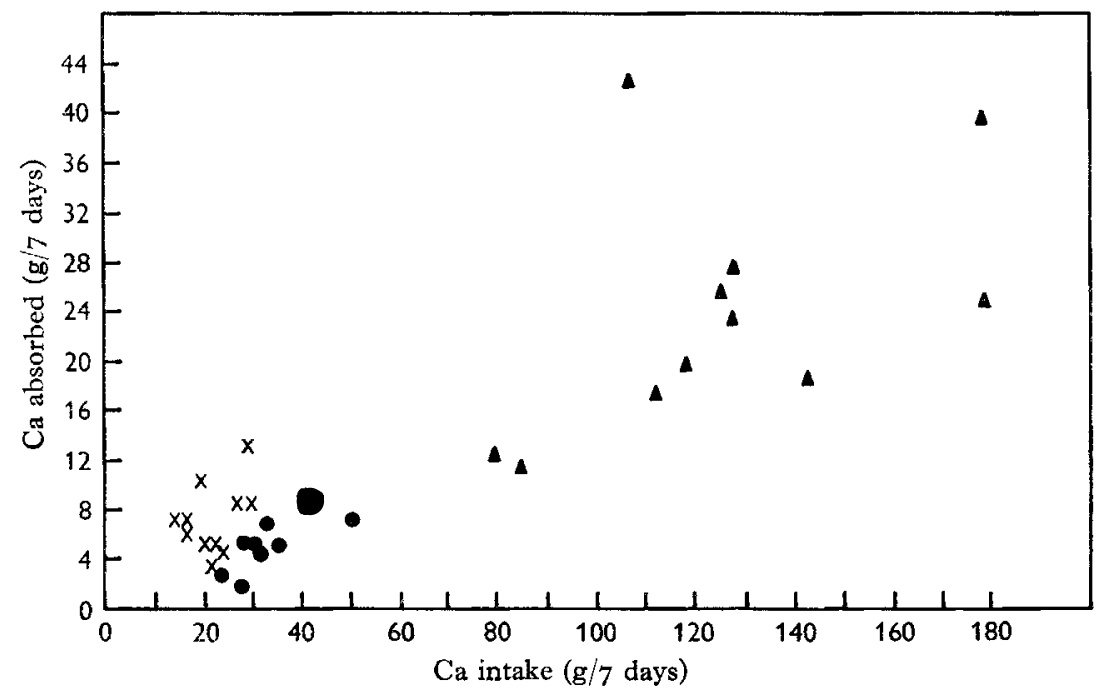

Fig. 1. Relationship between calcium intake and Ca absorption in sheep during period 2 (days $\left.\mathrm{I}_{4}-2, \mathrm{I}\right)$ after the introduction of diets of varying Ca:P ratio. $\bullet, 10 \cdot 4: \mathrm{I}$, deficient in $\mathrm{P}$; $X, 1 \cdot 9: 1$, adequate in $P ; \Delta, 9 \cdot 9: 1$, adequate in $P$.

Table 6 summarizes the changes which occurred in serum $P$ concentration in the P-depleted and control sheep during the metabolism study. The P-depleted sheep fed on diets 2 and 3 , both adequate in $P$, showed an increased serum $P$ concentration after 12 days on these diets. Serum $P$ concentration decreased slightly in the control sheep fed on diets 2 and 3 and this change probably reflects the differences between $P$ intake before and during the metabolism study. After 12 days of feeding on diet $I$, serum $\mathbf{P}$ concentration in control sheep had markedly decreased, to a mean value which was slightly higher than that in P-depleted sheep fed on this diet.

Table 6. Mean serum phosphorus concentration of experimental sheep before and during metabolism trials

\begin{tabular}{|c|c|c|c|c|}
\hline \multirow[b]{2}{*}{ Diet no. } & \multirow[b]{2}{*}{ Sheep } & \multicolumn{3}{|c|}{$\begin{array}{l}\text { Serum phosphorus concentration } \\
\text { (mg P/100 ml) }\end{array}$} \\
\hline & & Initial* & Day I $2 \dagger$ & Day $21 \uparrow$ \\
\hline I & $\begin{array}{l}\text { P-depleted (5) } \\
\text { Control (6) }\end{array}$ & $\begin{array}{r}3.55 \\
10.09\end{array}$ & $\begin{array}{l}3.94 \\
4.76\end{array}$ & $\begin{array}{l}3 \cdot 16 \\
4 \cdot 64\end{array}$ \\
\hline 2 & $\begin{array}{l}\text { P-depleted (5) } \\
\text { Control (6) }\end{array}$ & $\begin{array}{l}3 \cdot 48 \\
8 \cdot 78\end{array}$ & $\begin{array}{l}8 \cdot 54 \\
7 \cdot 42\end{array}$ & $\begin{array}{l}8 \cdot 02 \\
6.67\end{array}$ \\
\hline 3 & $\begin{array}{l}\text { P-depleted (5) } \\
\text { Control (6) }\end{array}$ & $\begin{array}{l}3 \cdot 93 \\
9 \cdot 42\end{array}$ & $\begin{array}{l}9 \cdot 90 \\
8 \cdot 21\end{array}$ & $\begin{array}{l}9 \cdot 5 I \\
8 \cdot 18\end{array}$ \\
\hline
\end{tabular}

Figures in parentheses are numbers of sheep/group.

* Taken 2-4 days before feeding with test diets.

$\uparrow$ Includes 4-day preliminary period. 


\section{DISCUSSION}

Concentration of serum inorganic $P$ was markedly affected by the level of $P$ intake, a finding which has been well documented previously (Ewer, I95 I; Martin \& Peirce, 1934). During the experimental P-depletion period of $I_{34}$ or I42 days, a rise in the serum $P$ concentration of control sheep was noted. This finding is of interest since it has been shown that the serum concentration of this element decreases with age in man, rat and dog (Howland \& Kramer, 1921 ; Bethke et al. 1923-4; Harrison \& Harrison, 194I). However, the physiological significance of the present finding is not clear.

Since Robison (1923) demonstrated the presence of alkaline phosphatase in bone, many workers have attempted to relate serum alkaline phosphatase activity to bone function. In man a close association between the degree of rickets and serum alkaline phosphatase activity appears to be well established. Rickets in children is due primarily to a deficiency of vitamin $D$ and the relationship between serum alkaline phosphatase activity and the severity of rickets conceivably might be different if the rachitic condition were associated directly with a dietary $\mathbf{P}$ deficiency, which is rare in man. Unfortunately, few studies are available in which serum alkaline phosphatase activity was measured in experimental animals fed on diets adequate in $\mathrm{Ca}$ and vitamin D but of varying P content. However, Miller, Ullrey, Zutaut, Baltzer, Schmidt, Hoefer \& Luecke (1964) found in baby pigs, given adequate vitamin D and $\mathrm{Ca}$, that serum alkaline phosphatase activity increased significantly on a low-P diet. The results obtained from the present experiments suggest that, as an indicator of deranged skeletal metabolism in the ruminant following $\mathbf{P}$ depletion but with adequate vitamin $\mathrm{D}$, measurement of serum alkaline phosphatase activity may have limited value. The activity of this enzyme was also found to increase in the control groups during the 142-day period. Furthermore, this increase is in contrast to findings in various simple-stomached species in which enzyme activity has been shown to decrease with age (Kay, 1930). This may suggest that the increase in serum alkaline phosphatase activity in the control sheep was due to an increasing contribution to the total serum activity of this enzyme by a source other than that of bone. The liver, kidney, or intestine may increase its contribution to the serum enzyme with age in the sheep. In man the major source of the enzyme appears to derive from bone (Schlamowitz \& Bodansky, 1959). Of significance, however, is the suggestion of Wilson \& Wilcox (1963) that the increased serum activity in an inbred strain of chicks was due to a greater contribution by intestinal tissue. More work is required to elucidate the significance of changes in serum alkaline phosphatase activity in the sheep.

Histological examination of the bones suggested that either late rickets or osteoporosis could be produced in 4- to 6 -month-old lambs by feeding them on a low-P diet supplying approximately $0.5-0.6 \mathrm{~g} \mathrm{P}$ daily, together with adequate vitamin $\mathrm{D}$. In part, these findings support those of Theiler (193I), who found rickets in P-deficient cattle, but differ with his results in that osteoporosis was also noted in some of our sheep. Ewer (195I) was not able to detect rickets in sheep on a diet supplying daily only $0.3 \mathrm{~g} \mathrm{P}$, with adequate vitamin $\mathrm{D}$. However, it should be noted that his findings may be explained by the fact that his sheep were 10 months old when introduced on 
to the diet; in addition, since he did not examine the bones histologically and depended on radiographs to establish a diagnosis, mild lesions of rickets could have been missed.

The presence of osteoporosis in the deficient sheep is of considerable interest since in the past it has been the common belief that diets deficient in $\mathrm{Ca}$ or $\mathrm{P}$ always result in rickets or osteomalacia. Recent investigations have shown, however, that osteoporosis may develop after the feeding of Ca-deficient diets (Jowsey \& Gershon-Cohen, 1964). A P deficiency does not appear to have been previously shown to cause the development of osteoporosis. Follis, Day \& McCollum (I940) found that in P-deficient rats, as growth ceased, the rickets began to heal, which might suggest that an osteoporosis then developed in these rats. The age at which an animal is introduced to a diet low in $\mathrm{Ca}$ or $\mathrm{P}$ and the subsequent growth rate of the animal have important effects on the degree of development of rickets as pointed out by Benzie, Boyne, Dalgarno, Duckworth, Hill \& Walker (1960).

Results from the present metabolism study show that a diet with a high $\mathrm{Ca}$ to $P$ ratio $\left(9^{\circ} 9^{: 1}\right)$ together with adequate $P$ does not result in a depressed absorption of dietary $P$. Furthermore, a high ratio does not prevent depleted sheep from responding to an adequate $\mathrm{P}$ intake. When the diet was deficient in $\mathrm{P}(0.076 \% \mathrm{P})$, the availability of $\mathrm{P}$ was reduced. A statistical analysis of the results suggests that the reduction was associated with the wide Ca: $\mathrm{P}$ ratio $\left(\mathrm{IO}_{4} 4: \mathrm{I}\right)$ of the $\mathrm{P}$-deficient diet and this supports the views expressed earlier (Theiler, I93 I Harris, I959) that the ratio of the elements may be more critical when the diet is deficient in the limiting element. However, as pointed out above, the reduced $P$ availability may be the result of factors other than the wide $\mathrm{Ca}: \mathrm{P}$ ratio, and further experimentation is required to verify these views.

The mean availability of the $\mathrm{P}$ of diet $\mathrm{I}$ during period 2 was approximately $8 \mathrm{I} \%$ of that found in sheep fed on diet 2. If the high concentration of $\mathrm{Ca}$ of diet $\mathrm{I}$ was responsible for the lowered availability of $\mathrm{P}$ this decrease represents a small effect per unit of $\mathrm{Ca}$ intake since there was sufficient $\mathrm{Ca}$ to precipitate (as tricalcium phosphate) more than five times the amount of $\mathrm{P}$ fed.

Analogous results have been reported by Thompson, Hansard \& Bell (1959), who showed that, when aluminium sulphate was fed to lambs in amounts sufficient to precipitate $85 \%$ of the dietary $\mathrm{P}$, the rate of $\mathrm{P}$ absorption was not impaired. They attempted to explain their findings on the basis of the work of Struthers \& Sieling (1950), who had found that certain organic anions, particularly those of some simpler organic acids, prevented aluminium from precipitating phosphate. Furthermore, Wise $e$ t al. ( 1963 ) found that young ruminants tolerated dietary $\mathrm{Ca}: \mathrm{P}$ ratios of up to 8: $\mathrm{I}$ before they noted a detrimental effect on performance. These workers suggest that ruminant animals have more highly developed physiological mechanisms for handling high levels of dietary $\mathrm{Ca}$ than non-ruminant animals which do not naturally subsist on diets with a wide $\mathrm{Ca}: \mathrm{P}$ ratio.

An alternative explanation of the findings of earlier workers and of those described in this paper might be reached by considering the intestinal interaction of these elements. According to Davis ( $1_{96} 6_{3}$, the theory generally held is that the effect of a wide dietary $\mathrm{Ca}: \mathrm{P}$ ratio results from a reduced $\mathrm{Ca}$ or $\mathrm{P}$ absorption following the precipitation of insoluble, and presumably unavailable, tricalcium phosphate at the 
alkaline $\mathrm{pH}$ commonly assumed to prevail in the upper intestinal tract. In view of our results and the generally different responses shown by ruminant and non-ruminant species to wide dietary ratios, it might be that the $\mathrm{pH}$ at the site of absorption of intestinal $\mathrm{Ca}$ or $\mathrm{P}$ differs between these two classes of animal.

The results of a search of the literature concerning intestinal $\mathrm{pH}$ are given in Table 7. They demonstrate that in the sheep the reaction in the upper small intestine is markedly more acidic than in the simple-stomached species. Since P appears to be absorbed from the upper small intestine in simple-stomached species (Weissberger \& Nasset, 1942-3; McHardy \& Parsons, 1956) and also in ruminants (Wright, I955; Chandler \& Cragle, 1962), it is suggested that $P$ may be absorbed from a more acidic environment in the sheep than in the rat, for example. The precipitation of $P$ as tricalcium phosphate would, therefore, be reduced; this may explain the present findings and the tolerance by ruminants to wide dietary $\mathrm{Ca}: \mathrm{P}$ ratios.

rable 7. $p H$ of intestinal contents of simple-stomached and ruminant species

\begin{tabular}{|c|c|c|c|}
\hline Species & Section of intestine & $\begin{array}{c}\mathrm{pH} \text { of } \\
\text { contents }\end{array}$ & Reference \\
\hline Man & $\begin{array}{l}\text { Stomach } \\
\text { Duodenum } \\
\text { Lower ileum }\end{array}$ & $\begin{array}{l}2 \cdot 0-5 \cdot 0 \\
6 \cdot 0 \\
8 \cdot 0\end{array}$ & $\begin{array}{l}\text { Borgström, Dahlqvist, } \\
\text { Lundh \& Sjövall (1957) }\end{array}$ \\
\hline Rat & $\begin{array}{l}\text { Small intestine (I) } \\
\text { Small intestine (2) } \\
\text { Small intestine (3) } \\
\text { Caecum } \\
\text { Colon }\end{array}$ & $\begin{array}{l}6 \cdot 4-6 \cdot 6 \\
6 \cdot 7-6 \cdot 9 \\
6 \cdot 9-7 \cdot 3 \\
6 \cdot 6-7 \cdot 3 \\
7 \cdot 0-7 \cdot 3\end{array}$ & Robinson \& Duncan (I93I) \\
\hline Pig & $\begin{array}{l}\text { Duodenum } \\
\text { Middle jejunum } \\
\text { Lower ileum }\end{array}$ & $\begin{array}{l}3 \cdot 0-6 \cdot 0 \\
5 \cdot 0-6 \cdot 5 \\
6 \cdot 5-7 \cdot 5\end{array}$ & Møllgard (I946) \\
\hline Sheep & $\begin{array}{l}\text { Lower duodenum } \\
\text { Upper jejunum } \\
\text { Middle small intestine } \\
\text { Distal small intestine }\end{array}$ & $\begin{array}{l}2 \cdot 5-3 \cdot 2 \\
3 \cdot 1-4 \cdot 5 \\
7 \cdot 9-8 \cdot 1 \\
8 \cdot 0-8 \cdot 3\end{array}$ & Phillipson \& Storry (1965) \\
\hline
\end{tabular}

The major source of dietary $\mathrm{P}$ in the present experiments was soluble, anhydrous $\mathrm{NaH}_{2} \mathrm{PO}_{4}$ with no detectable phytate $\mathrm{P}$ in the diets. It has also been shown that an interaction exists between the dietary $\mathrm{Ca}: \mathrm{P}$ ratio and the form of $\mathrm{P}$ given. When the major proportion of the dietary $P$ is in the form of phytin $P$, a wide dietary ratio appears to exert a greater effect on the performance of the animal than when the source of dietary P is inorganic phosphate (Krieger \& Steenbock, 1940). Since it is generally agreed that ruminants are able to utilize phytate $\mathrm{P}$ more efficiently than the non-ruminant species (Mills \& Williams, I96r), the interaction between the ratio of $\mathrm{Ca}$ and $\mathrm{P}$ and the source of $\mathrm{P}$ is likely to be less important in ruminants than in other species.

The above facts taken together appear to offer a reasonable explanation of the effects, found in the present experiments, of the dietary $\mathrm{Ca}: \mathrm{P}$ ratio on $\mathrm{P}$ absorption. Consideration of the comparative aspects of phytate $P$ utilization and the intestinal reaction in various species leads also to the hypothesis that these two factors play an 
important part in determining the extent to which wide ratios are tolerated under both practical and experimental feeding regimens. With the successful development of intestinal fistulation techniques, verification of this hypothesis appears possible.

When the $\mathrm{P}$ intake of the depleted sheep was raised to an adequate level, they showed a higher efficiency of dietary $\mathrm{P}$ absorption than the controls. This effect appears to parallel results on $\mathrm{Ca}$ realimentation and absorption reported previously by many workers (see Henry \& Kon, 1953). Whether the results are suggestive of an active mechanism or merely reflect a higher electrochemical potential difference between the gut lumen and plasma is not known. Since the serum $P$ concentrations of the depleted sheep increased after the provision of adequate $P$ ('Table 6), it would seem that a change in the electrochemical potential difference might best explain the less efficient absorption by these sheep during period 2. This reasoning would also be in line with the suggestion that $\mathrm{P}$ absorption appears to occur via a process of passive diffusion (McHardy \& Parsons, r956). This is, however, still not entirely clear; the work of Harrison $\&$ Harrison (196r) suggests that diffusion does not account entirely for phosphate transfer.

As in earlier findings (Lueker \& Lofgreen, 196I), the rate of $\mathrm{Ca}$ absorption increased with increasing $\mathrm{Ca}$ intake when the diet contained adequate $\mathrm{P}$. The present results suggest that a $\mathrm{P}$-deficient diet results in a reduced rate of $\mathrm{Ca}$ absorption. Recently, a close correlation between the rates of bone anabolism and $\mathrm{Ca}$ absorption was demonstrated (Bronner, 1964). Therefore, the reduced rate of $\mathrm{Ca}$ absorption noted in our experiments may be caused by a reduced rate of bone anabolism resulting from a P-deficient diet. In our experiment, moreover, in the depleted sheep receiving the deficient diet rates of bone anabolism and catabolism were lower than in controls receiving adequate $\mathrm{P}$ (Young, 1964 ; Young et al. 1966). This may explain the reduced $\mathrm{Ca}$ absorption rate, because it has been found on numerous occasions that the degree of skeletal $\mathrm{Ca}$ saturation influences the rate of $\mathrm{Ca}$ absorption. The lower the skeletal saturation then the higher the apparent absorption of $\mathrm{Ca}$. Although the depleted sheep fed on diet I had lower Ca stores than the control sheep fed on diet $\mathbf{2}$ and although the Ca intake of the depleted sheep was significantly greater than that of the controls, the rate of absorption in these two groups did not differ significantly. It appears that $\mathrm{P}$ intake should be adequate before enhanced $\mathrm{Ca}$ absorption can occur. As more information is gathered on the skeletal metabolism of animals under varying dietary conditions its precise role and importance in controlling $\mathrm{Ca}$ absorption should receive further clarification.

We acknowledge the valuable assistance of J. Bryan, B. Chew and N. Hinmann.

\section{REFERENCES}

Association of Official Agricultural Chemists (1960). Official Methods of Analysis, 9th ed. Washington, DC: Association of Official Agricultural Chemists.

Aubert, J.-P., Bronner, F. \& Richelle, L. J. (1963). F. clin. Invest. 42, 885.

Benzie, D., Boyne, A. W., Dalgarno, A. C., Duckworth, J., Hill, R. \& Walker, D. M. (ig60). F. agric. Sci., Camb. 54, 202 .

Bethke, R. M., Steenbock, H. \& Nelson, M. T. (1923-4). F. biol. Chem. 58, 7 I.

Borgström, B., Dahlqvist, A., Lundh, G. \& Sjövall, J. (I957). F. clin. Invest. 36, I 52 1. 
Bronner, F. (1964). In Mineral Metabolism. Vol. 2, part A, ch. 2o. [C. L. Comar and F. Bronner, editors.] New York: Academic Press Inc.

Chandler, P. T. \& Cragle, R. G. (1962). Proc. Soc. exp. Biol. Med. III, 43 I.

Davis, G. K. (1963). In The Transfer of Calcium and Strontium across Biological Membranes, pp. 129-142. [R. H. Wasserman, editor.] New York: Academic Press Inc.

Dowe, T. W., Matsushima, J. \& Arthaud, V. H. (1957). F. Anim. Sci. 16, 81 I.

Ewer, T. K. (195 I). Br. F. Nutr. 5, 287.

Follis, R. H. Jr, Day, H. G. \& McCollum, E. V. (1 940). F. Nutr. 20, 181.

Hansard, S. L. \& Plumlee, M. P. (1954). F. Nutr. 54, 17.

Harris, L. E., Bassett, C. F. \& Wilke, C. F. (1951). F. Nutr. 43, 153.

Harris, R. S. (1959). Fedn Proc. Fedn Am. Socs exp. Biol. 18, 1100.

Harrison, H. E. \& Harrison, H. C. (194I). J. clin. Invest. 20, 47.

Harrison, H. E. \& Harrison, H. C. (1961). Am. F. Physiol. 200, 1007.

Henry, K. M. \& Kon, S. K. (I953). Br. F. Nutr. 7, I47.

Hill, R. (1963). In World Revicw of Nutrition and Dietetics. Vol. 3, p. I3r. [G. H. Bourne, editor.] New York: Hafner Publishing Co. Inc.

Howland, J. \& Kramer, B. (x921). Am. F. Dis. Child. 22, 105.

Huffman, C. F., Robinson, C. S. \& Winter, O. B. (1930). F. Dairy Sci. r3, 432.

Jowsey, J. \& Gershon-Cohen, J. (1964). Proc. Soc. exp. Biol. Med. 116, 437.

Kay, H. D. (1930). F. biol. Chem. 89, 235.

Kleiber, M., Smith, A. H., Ralston, N. P. \& Black, A. L. (I95I). Y. Nutr. 45, 253.

Krieger, C. H. \& Steenbock, H. (1940). F. Nutr. 20, 125.

Lloyd, L. E., Crampton, E. W. \& Mowat, D. N. (I961). F. Anim. Sci. 20, 176.

Lowry, O. H. (1957). In Methods in Enzymology. Vol. 4, p. 37ı. [S. P. Colowick \& N. O. Kaplan, editors.] New York: Academic Press Inc.

Lueker, C. E. \& Lofgreen, G. P. (I96r). F. Nutr. 74, 233.

Luick, J. R., Boda, J. M. \& Kleiber, M. (1957). F. Nutr. 6r, 597.

Martin, C. J. \& Peirce, A. W. (1934). Bull. Aust. Coun. Sci. Industr. Res. no. 77.

McCollum, E. V., Simmonds, N., Shipley, P. G. \& Park, E. A. (1921). F. biol. Chem. 47, 507.

McHardy, G. J. R. \& Parsons, D. S. (I956). Q. Fl exp. Physiol. 4I, 398.

Miller, E. R., Ullrey, D. E., Zutaut, C. L., Baitzer, B. V., Schmidt, D. A., Hoefer, J. A. \& Luecke, R. W. (1964). F. Nutr. 82, 34.

Mills, C. F. \& Williams, R. B. (I96I). F. Sci. Fd Agric. 12, 592.

Møllgard, H. (r946). Biochem. $¥ .40,589$.

Mraz, F. R. (I961). F. Nutr. 73, 409 .

Phillipson, A. T. \& Storry, J. E. (I965). F. Physiol., Lond. I81, I30.

Rasmussen, H. \& DeLuca, H. F. (1963). Ergebn. Physiol. 53, 108.

Robinson, C. S. \& Duncan, C. W. (I93I). F. biol. Chem. 92, 435.

Robison, R. (1923). Biochem. F. 17, 286.

Rottensten, K. V. (1938). Biochem. F. 32, 1285.

Schlamowitz, M. \& Bodansky, O. (1959). F. biol. Chem. 234, I 433.

Struthers, P. H. \& Sieling, D. H. (I950). Soil Sci. 69, 205.

Theiler, A. (1931). Vet. Rec. II, I143.

Theiler, A., duToit, P. J. \& Malan, A. I. (1937). Onderstepoort J. vet. Sci. Anim. Ind. 8, 375.

Thompson, A. (1965). Proc. Nutr. Soc. 24, 81.

Thompson, A., Hansard, S. L. \& Bell, M. C. (1959). F. Anim. Sci. r8, 187.

Weissberger, L. H. \& Nasset, E. S. (1942-3). Am. F. Physiol. 138, 149.

Wilson, H. R. \& Wilcox, F. H. (1963). Proc. Soc. exp. Biol. Med. 113, 413.

Wise, M. B., Ordoveza, A. L. \& Barrick, E. R. (1963). F. Nutr. 79, 79.

Wright, E. (1955). Nature, Lond. I76, 35 I.

Young, V. R. (1964). Some aspects of calcium and phosphorus metabolism in sheep, with special reference to the effects of phosphorus depletion and the dietary calcium:phosphorus ratio. Thesis, University of California.

Young, V. R., Luick, J. R. \& Lofgreen, G. P. (I966). Br. F. Nutr. 20, 727.

\section{EXPLANATION OF PLATE}

Photomicrographs of the first rib of a sheep, about $1 \mathrm{~cm}$ dorsal to the costochondral junction. Haematoxylin and eosin.

(a) Phosphorus-deficient sheep: shows severe osteoporosis with a thin cortex and trabeculae which are reduced in size and number.

(b) Control sheep: note the well-developed cortex and trabeculae in contrast to that shown in $(a)$. 
British fournal of Nutrition, Vol. 20, No. 4
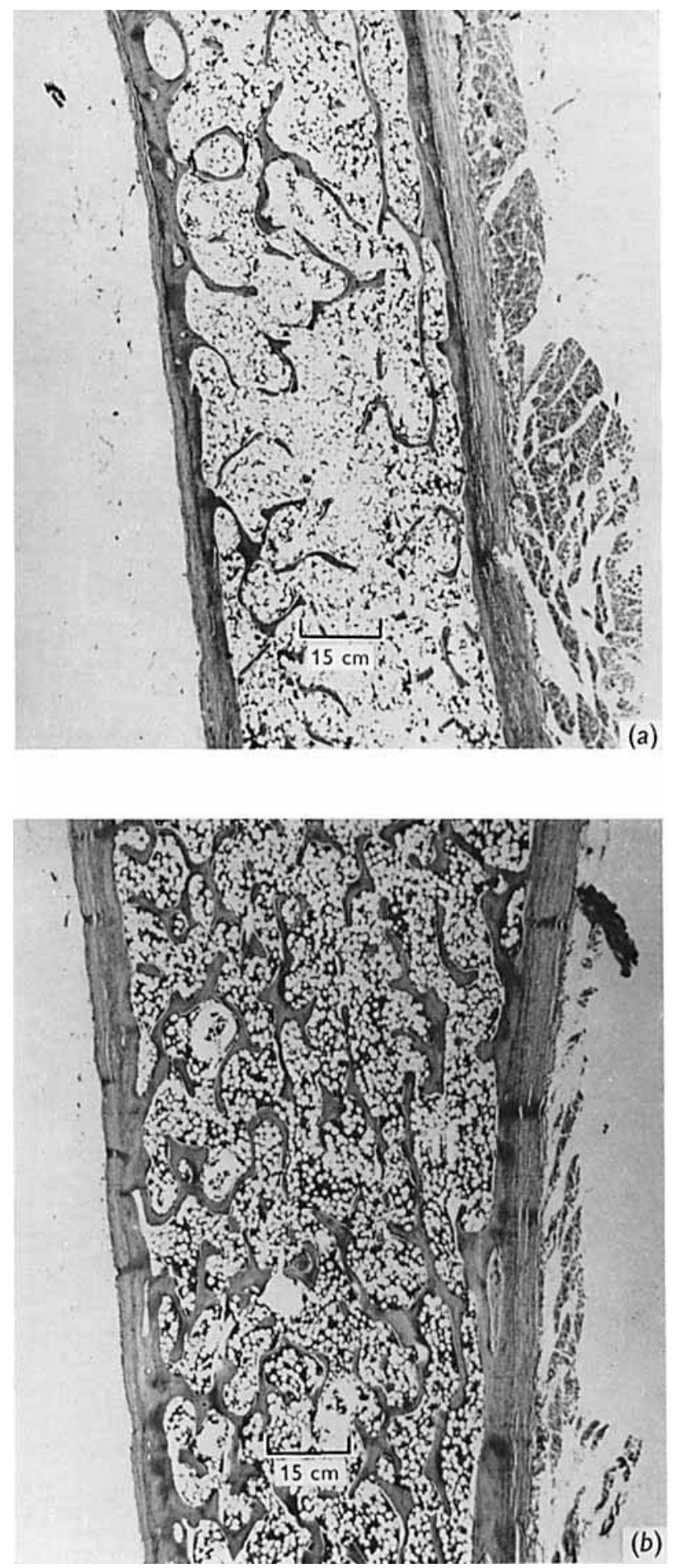